Please do not remove this page

RMIT

UNIVERSITY

\title{
Broadband as Civic Infrastructure: The Australian Case
}

McShane, Ian; Wilson, Christopher; Meredyth, Denise

https://researchrepository.rmit.edu.au/esploro/outputs/9921859574601341/filesAndLinks?institution=61RMIT_INST\&index=null

McShane, I., Wilson, C., \& Meredyth, D. (2014). Broadband as Civic Infrastructure: The Australian Case.

Broadband Futures: Content, Connectivity and Control, 151, 127-136.

https://researchrepository.rmit.edu.au/discovery/fulldisplay/alma9921859574601341/61RMIT_INST:Resea rchRepository

Document Version: Accepted Manuscript

Repository homepage: https://researchrepository.rmit.edu.au

(C) 2014 University of Queensland

Downloaded On 2023/04/26 22:55:43 +1000

Please do not remove this page 
Thank you for downloading this document from the RMIT Research Repository.

The RMIT Research Repository is an open access database showcasing the research outputs of RMIT University researchers.

RMIT Research Repository: http://researchbank.rmit.edu.au/

\section{Citation:}

McShane, I 2014, 'Broadband as Civic Infrastructure: The Australian Case', Broadband Futures: Content, Connectivity and Control, vol. 151, pp. 127-136.

See this record in the RMIT Research Repository at:

https://researchbank.rmit.edu.au/view/rmit:24719

Version: Accepted Manuscript

Copyright Statement: (c) 2014 University of Queensland

Link to Published Version:

http://www.uq.edu.au/mia/2014-issues\#151

\section{PLEASE DO NOT REMOVE THIS PAGE}


Broadband as Civic Infrastructure - the Australian Case

Ian McShane - Centre for Urban Research, RMIT University

Chris Wilson- Centre for Urban Research, RMIT University

Denise Meredyth-Centre for Urban Research, RMIT University

Corresponding author: ian.mcshane@rmit.edu.au 


\title{
Broadband as Civic Infrastructure - the Australian Case
}

\begin{abstract}
Australian municipal governments have lagged behind many of their international counterparts in local public broadband provision. However, by 2014 there are signs that the gap is closing, with significant new investment in public Wi-Fi by city governments across Australia. This article contextualises the current interest in public Wi-Fi by analysing international developments in municipal broadband and the spasmodic involvement of Australian local authorities in this field. We argue that the rhetoric of broadband as a 'fourth utility' unduly prioritises the role of higher governments in Australia, constraining a full exploration of how broadband might be imagined as a form of civic infrastructure.
\end{abstract}

\section{Introduction}

Digital inclusion has emerged as a major theme in the strategic planning of Australian local government authorities (LGAs) and in the advocacy work of state and national associations representing the sector (Australian Local Government Association, 2012). This is welcomed by advocates who regard broadband as civic or community-level infrastructure essential to the twenty-first century (Greco, 2010). Nevertheless, Australian local authorities have taken few steps towards treating broadband as a local public good and common resource, as important to plan and provide for as roads, parks or cultural amenities.

The Australian situation contrasts with many other countries. Municipal governments on several continents have long been active developers or partners in constructing local 
broadband networks, with 'municipal broadband' a recognised typology of broadband provision (Middleton, 2007). In Australia the argument for municipal investment in broadband is still experimental. Municipal administration in Australia is distinctive by its comparatively small jurisdiction. The local government sector has a limited fiscal base and service role, while telecommunications and other networked utilities are organised by higher levels of government, as in the case of the Australian government's current construction of a national broadband network.

Things may be changing however. There is a trend towards investment by LGAs in public Wi-Fi initiatives, offering free internet access in public spaces using wireless technology. These initiatives are driven by strong local enthusiasm, but they often lack a clear strategic vision; they generally show little awareness of what has been tried before, either in Australia or internationally. In fact, research on international parallels in public Wi-Fi initiatives shows a mixed record of success and stubborn political, commercial and technological problems that recur, due to the way in which arguments for investment, public benefit and civic entitlement have been framed. Australian public Wi-Fi advocates may be able to avoid these traps and find a clearer vocabulary.

We argue that it is not helpful to frame the argument for local government provision of public Wi-Fi in terms of government's obligation to provide citizens with access to broadband as a 'fourth utility' (Conroy 2009). The argument has been made effectively in other national settings, but it fails to work in Australia, where local government authorities have not been involved in utility provision, though they do provide an increasing range of community services (PricewaterhouseCoopers, 2006). Arguments based on citizens' rights to broadband as a fourth utility actually encourage local government to defer responsibility for broadband 
provision to state and Commonwealth agencies, or to markets and private providers. The argument reinforces unhelpful distinctions between digital infrastructure and the community and urban infrastructures that are the province of Australian LGAs.

This article nudges the debate in a different direction. We argue that there is little to be gained by urging Australian LGAs to follow some overseas counterparts and set up as broadband retailers. There is however a strong case for extending public access to broadband as part of a suite of integrated local services and amenities, to address concerns over digital inclusion, and to promote social and economic innovation. However, we also argue that the extension of LGA involvement in this area requires a clear understanding of how the provision of broadband as a local public good sits within a wider broadband ecology and information economy (Middleton and Bryne 2011). There is a good case for Australian local government to widen its jurisdiction and provide public access to Wi-Fi as a service and amenity - not least because the social services and amenities that they now provide are increasingly available online, and therefore unaffordable or inaccessible for many.

This article is divided into three sections. First, we examine the trajectory of international developments in local public broadband provision and the terms in which success and failure have been understood. In section two we outline the history of Australian LGA involvement in public broadband provision and analyse the current state of play in an environment dominated by the roll-out of the National Broadband Network (NBN). The final section critiques the 'fourth utility' concept and argues for re-imagining broadband as a form of civic infrastructure. 


\section{Municipal Broadband Internationally}

International developments in this field have been well documented. City governments and local utility companies experimented with a range of wired broadband platforms and business models during the 1990s. However, it was the 1999 release of technical standards for access to non-regulated wireless spectrum that sparked a wave of investment in local broadband in the form of public Wi-Fi networks by municipal governments, utility companies and civil society organisations, particularly in North America and Europe. Investment continued through the 2000s, generating predictions of ubiquitous public Wi-Fi coverage (Visiongain, 2006). This failed to materialise and investment stalled in the mid-to-late 2000s as local authorities confronted a range of political, regulatory, commercial and technological challenges.

Investment rationales during this first phase of public Wi-Fi initiatives were complex and sometimes conflicting, and municipal entrepreneurship was resisted by incumbent telecommunication companies, higher governments and local taxpayers (Troulos and Maglaris, 2011; Tapia et al., 2011; Van Oost et al., 2011; Middleton, 2007; Matson and Mitchell, 2006; Powell and Shade, 2006; Gillett et al., 2004). While there is no consensus in the literature that municipal broadband dampens innovation or competition (Powell, 2009; Hauge et al., 2008; Santorelli, 2007), a pro-market stance underpins broadband policies in many parts of the globe. In Europe, direct or financial support by municipalities must be compliant with European Union (EU) state aid rules. In the US, incumbent providers and state governments buttressed competition through court and legislative action to restrict municipal investment (Jassem, 2010; Federal Communications Commission, 2010). 
After a brief hiatus, we are beginning to see renewed enthusiasm from municipal government for public Wi-Fi initiatives. The commercial, regulatory, technological and social settings that surround public Wi-Fi have changed substantially in the past few years. The release and rapid uptake of Wi-Fi enabled mobile devices, the declining costs and technical complexity of wireless equipment, moves to engineer seamless network access and handover, and new forms of collaboration between the commercial and public sectors have all underpinned new public Wi-Fi investment. The latter change is important. Telcos are now actively supporting municipal governments in their public Wi-Fi endeavours since they recognise that offloading data traffic onto such networks is imperative to easing congestion on their $3 \mathrm{G}$ and $4 \mathrm{G}$ networks (Aijaz et al., 2013).

Hartmann (2009) and Middleton (2007) argue that there has been insufficient public debate over the rationales, forms of provision, and futures of municipal broadband networks. Middleton (2007) doubts the wisdom of municipal investment in this field, specifically in WiFi networks, on a number of grounds: quality of service, unsustainability of business models and mismatch with user needs. Some evaluations of municipal broadband networks have identified economic benefits (Ford and Koutsky, 2005; Strategic Economic Solutions, 2007), although the literature in this area is not robust. The failure of private sector-driven 'pri-fi' projects in several US cities has cast doubt on the capacity of local governments to effectively transfer risk in partnership ventures, and is cited as proof of the wider failure of public broadband (Community Broadband Networks, 2012; Middleton, 2008).

More troublingly, though, analysis of municipal and community-based broadband has questioned whether these initiatives break down or reproduce existing patterns of digital exclusion. Sandvig (2004) observed a correlation between the construction of municipal 
networks and existing high levels of broadband uptake. Further, Fuentes-Battista and Inagaki (2006) argue that some community networks have been unable to shrug off charges of elitism, with network access filtered by social as much as technical capital. In this light, 'digital exclusion' is framed by a wider politics of community, rather than connectivity and digital literacy.

Alternatively, over-ambitious projections for broadband connectivity and growth, particularly in disadvantaged areas, have proved fatal to network sustainability (Troulos and Maglaris, 2011; Middleton, 2007). Rolling out demonstration projects or targeting low-income areas is likely to produce low uptake and apparent lack of success. Powell and Shade (2006) observe that the sustainability of community networks in Canada has been threatened by narrow performance criteria such as cost-covering, rather than broader, if less tangible assessments of the value of these networks.

\section{Australia by contrast}

In contrast to many other countries, Australian LGAs have had little direct involvement in broadband provision. Predominantly, where the local government sector in Australia has focused on broadband, it has done so in terms of demand and access rather than supply. While there is a history of local broadband experimentation in Australia, it has been conditioned by jurisdictional power, roles and capacities, and a pro-market regulatory environment.

Molony's (2006) assessment of local government broadband initiatives between 1995 and 2005 shows a period of experimentation, particularly in regional areas, which both responded 
to concerns over market liberalisation and explored new opportunities it presented. Local authorities were involved in establishing local telco cooperatives, installing fibre circuits, and participating in Wi-Fi and WiMax trials. At least four electricity supply companies experimented with broadband over powerlines, conducting small-scale trials in metropolitan and country areas. Other organisations investigated the particular technological, economic and cultural challenges of delivering telecommunications to remote Indigenous communities (Rennie et al., 2010). The Melbourne municipalities of Darebin, Yarra and Whitehorse partnered with the not-for-profit organisation InfoXchange to provide connectivity, computer equipment and training to tenants on public housing estates or low-income residents (Greco, 2010; Meredyth et al., 2006). At least some of these activities were funded by the national government through the Networking the Nation (NTN) scheme, established with revenue from the part sale of the legacy provider Telstra beginning in 1997 (Department of Communications, Information Technology and the Arts, 2006).

By 2005, much of this experimentation by local authorities had ceased, with commentators pointing to the risks presented by a rapidly evolving telecommunications landscape (Braue, 2008). While it is not coincidental that NTN funding had wound up, the Australian government's 2004 National Broadband Strategy (NBS) now dominated the policy landscape. NBS sought to balance a pro-competitive regulatory environment with the capacity of governments to step in where market failure was evident (Department of Communications, Information Technology and the Arts, 2004).

NBS was accompanied by a series of action plans, including one for the local government sector, which the Australian Local Government Association (ALGA), the sector's national peak body, was charged with implementing. ALGA focussed on applying NBS principles in 
the context of the NBN rollout, urging councils to bargain for faster and cheaper broadband in their jurisdictions, contending that demand aggregation counters market and higher government failure. While calling on councils to identify and define a role in the development and delivery of broadband services as part of a "broadband vision", ALGA nevertheless suggested that broadband provision is more appropriately a role for commercial telecommunications carriers (Australian Local Government Association, 2012).

With the national government's wholesale broadband network reserved for commercial retail, recent interest by state and local governments has focussed on the provision of public Wi-Fi. Research by Lambert et al. (2013) and our own sampling of local authorities and civil society organisations have identified at least 30 recent Wi-Fi network deployments across all Australian states, including smaller cities and regional tourist destinations, and on four public transport systems. Some of these initiatives are flagged in local authority digital strategies, sprinkled with the rhetoric of 'smart city' and 'connected community' (Adelaide City Council, 2013; Parramatta City Council, 2010). Others have emerged without a clear link to local authority policy or strategic plans, but appeal for local voter support through references to the network's benefits for digital inclusion, economic vitality, service provision and civic participation. Such claims have yet to be tested in the nascent Australian scene.

While many Australian local authorities have experience of wireless technologies through public internet provision in municipal libraries, telecommunication hardware companies and network developers are vigorously promoting expansion into public spaces by offering readymade technological solutions (Ruckus Wireless, 2013). There is also evidence that Australian telcos who, like their international counterparts, are facing increasing congestion on their $3 \mathrm{G}$ and 4G mobile networks through spiraling data traffic, have begun promoting cooperative 
opportunities to local authorities for the establishment of public Wi-Fi networks (Dow, 2013). Australian LGAs are uniquely positioned to provide the distributed physical infrastructure (such as lightpoles) for mounting wireless access points required by short-range Wi-Fi networks.

Announcements of Wi-Fi deployments by Australian local governments indicate strong intercity rivalry and tend to polarise local opinion (for example Higgins, 2012). Supporters commonly urge Australian city governments to catch up with international developments. The frequent designation of public Wi-Fi as free attracts considerable negative comment from ratepayers, especially those beyond network range. Higher governments, too, have cast a critical eye over local authority initiatives. In 2014, the City of Melbourne's plans to trial public Wi-Fi deployed by a major telco was thwarted by the Victorian state government's announcement of state-funded trials in Melbourne and two regional Victorian cities, Ballarat and Bendigo, and on selected regional rail services (Dow, 2013; Willingham, 2014). In contrast to the City of Melbourne's development path, the state government sought to promote competition and innovation through an open tender process.

Diverse models of Wi-Fi provision also highlight problems with the simple attribution of a network as 'public'. Clearly, Wi-Fi available in shopping centres or McDonalds is a private service designed to attract customers. The City of Darebin, a middle ring Melbourne municipality, provides $\mathrm{Wi}-\mathrm{Fi}$ in two retail strips; it is accessed by obtaining a code from participating local businesses such as cafes. What distinguishes this venture from McDonalds, save for its underwriting by public funds? Rather than seeking to clarify the elusive notion of 'public' in this setting, our concept of civic infrastructure acknowledges the hybrid arrangements through which local-level infrastructure has typically been provided and 
managed in Australia, often involving contributions from government, community and business groups (McShane 2010).

A good example of broadband as civic infrastructure is the Wi-Fi service established in Goulburn, New South Wales in 2013 by a community development and environmental group, using spare bandwidth donated by main street businesses and supported by a modest council grant. Goulburn was a prosperous regional city and centre of the Australian wool industry that has struggled economically in recent times. While residents point to the comparatively early arrival of ADSL technology to Goulburn, the delayed schedule for the city's connection to NBN has caused significant concern. Seeking to promote a new city image and revitalise Goulburn's main street following a highway bypass and extended drought, the group adapted a characteristically local approach to physical infrastructure to digital provision. As the group comments "[n]ow people have a reason to come into town and not just stop at McDonalds" (The Goulburn Group, 2013).

While Wi-Fi is neither ubiquitous nor free in Australian cities, it appears to be increasing in supply through diverse institutional arrangements. In such a scenario, what is the specific role for local government? The terms of this debate could be clarified by a stronger understanding of the relationship between broadband and the services, amenities and infrastructure for which local government has been responsible in Australia as elsewhere. The following section tackles this task. 


\section{Beyond supply and demand - assessing the public benefit of municipal broadband}

Compressed air was once promoted as the 'fourth utility' (Talbott, 1993), inviting critical scrutiny of the term's application to broadband. Access to broadband is widely acknowledged as essential to social and economic participation in the twenty-first century, although its status as a public utility warranting regulation is vigorously disputed (Crawford, 2013). Setting this argument to one side, however, the 'fourth utility' label calls up a century-old tradition of government intervention in Australia that may act as a barrier to local government initiatives. However, the growing interest of Australian local authorities in public Wi-Fi provision, and its relationship to fixed-line broadband access, $3 \mathrm{G}$ and $4 \mathrm{G}$ mobile services, and private $\mathrm{Wi}-\mathrm{Fi}$, has yet to be critically examined in policy, public finance, and practical service terms.

At a conceptual level, Powell (2009) argues that local broadband is usefully imagined as a public park, rather than a public utility. The park metaphor, for Powell, suggests both meeting place and play space, a place for community dialogue, enjoyment, social learning and activism. Gans (2007) takes a similar view, arguing that broadband's spillovers are most directly realised at a local level, giving it the characteristic of a local public good, more like garbage collection than defence. Alternatively, Goggin (2007) approaches spectrum and wireless technologies as common pool resources, attempting to open up mainstream Australian policy discussions focussed exclusively on telecommunications as public or private goods. Potts (2014) is also sceptical of existing rationales for providing Wi-Fi as a public good, citing ample private provision and setting out a range of alternative mechanisms, such as vouchers, to enable public internet access. Rather, Potts imagines public Wi-Fi as an arena of policy and practical experimentation, arguing that local governments should host 
test-bed environments to encourage innovation and new economic activity. In this scenario, investment in public broadband would not be directed to achieve known goals and outcomes, but to discover and coordinate new knowledge and leverage local entrepreneurship.

However, we argue there is a strong case for including effective broadband and internet access, through connectivity, equipment and training, within the suite of community services offered by municipal, health and housing organisations. Current Australian government policy on 'structural separation', or the withdrawal of Telstra, the former public monopoly, from the wholesale market, is projected to drive down telecommunications costs through competition, bringing them into line with other OECD countries (OECD, 2011).

Telecommunications providers have diversified offerings in recent years, introducing basic and relatively low-cost fixed line and mobile plans. Morsillo (2012) and Ewing and Thomas (2012), though, have shown that while there is almost universal broadband access in Australia's more affluent households, almost four in ten of the lowest income group do not have home broadband. Digital disconnection is often associated with other factors of disadvantage, such as homelessness, that may have complex causes and require multi-level solutions (Eynon and Geniets, 2012; Newman et al., 2010). In the Australian setting, LGAs are unlikely to provide what Middleton (2008) calls 'primary' broadband, or services to the home. However, in some instances, access to a 'secondary' form of local public broadband may be the only connectivity option available for this population cohort.

The current rivalry of major Australian city governments around Wi-Fi, though, diverts attention from underlying issues of coordination. In recent years, a shift towards multi-level and partnership forms of governance in Australia and internationally, has eroded fixed views on jurisdictional roles and responsibilities in favour of mobilising the resources of 
governments, civic organisations and businesses to find innovative solutions to endemic or emerging problems. Recent moves to share facilities and infrastructure provided by different levels of Australian governments - using schools left empty on weekends is a prime example - hold the promise of more efficient and productive uses of local assets. However, digital infrastructure has been left out of the picture here. Higher governments have spent substantial funds on the digital resources of schools, but municipal libraries, which are the backbone of Australia's public internet, strain to meet demand. In Victoria schools are serviced by an optical fibre network, but across Australia less than half the municipal public libraries have fast broadband connections, and many have difficulty funding the service (Australian Library and Information Association, 2011). In 2003, the Commonwealth government rejected an Australian Senate committee recommendation that public libraries be supported by an e-rate to fund their internet services: market competition would solve the problem (Minister for Communications, 2004). The current Australian picture is one of under-resourced and uncoordinated digital infrastructure. This could be remedied before any grander plans were hatched.

Australian local authorities are diverse in size, capacities and appetite for risk, whether political or commercial. In particular, the ICT capabilities of Australian municipalities vary widely (Purser, 2011). Encouraging greater local government experimentation with public broadband would require structural reform, to avoid exacerbating disparities within the sector, especially between metropolitan and rural councils. The first reform target could be the process of fiscal equalisation that redistributes higher government grants across the local government sector. Broadband could be recognised as a specific criterion in the schedule of cost adjustments used by state government grants commissions to ensure that all local governments have sufficient resources to provide sustainable and quality services (Victorian 
Grants Commission, 2013). Currently, road networks are identified as 'cost adjustors', but digital networks are not. Thinking beyond current conceptual distinctions between physical and digital in the local public realm, and beyond conventional policy paradigms, is a significant challenge for local officials in Australia and elsewhere.

\section{Conclusion}

National telecommunications markets, regulatory policies, traditions of public intervention, and the organisation of utility provision are major influences on municipal broadband internationally. In Australia, the limited constitutional and fiscal powers of the local government sector provide a ready explanation for constraints around local broadband. The rollout of NBN as a national wholesale monopoly has reinforced this view.

Our review of international municipal broadband initiatives shows that the initial enthusiasm for local investment in broadband networks encountered sustained scepticism about the benefits of public investment and the importance of unfettered competition and private choice. Middleton (2007) encapsulates this view, in arguing that while the underlying objectives of delivering reliable and accessible broadband to citizens should not be abandoned, municipal-level investment in networks may not be the best solution. However, Sylvain (2012) issues a significant challenge in claiming that 'all broadband is local'. What is the appropriate role of Australian local authorities in providing the infrastructure of the twenty-first century?

We have argued that while the 'fourth utility' metaphor raises the important question of access rights, it circumscribes the role of Australian local authorities. In preferring the 
metaphor of broadband as a public park rather than a public utility, we bring local governments to centre stage. Australian local governments play an important role in community building and civic participation through the provision of social infrastructure. They also play a part not simply in compensating for higher government and market failure in social service provision, but in marshalling the local knowledge and accountability that is so crucial for effective governance. Initiatives in the broadband field are, we argue, usefully framed in these terms. Similarly, thinking about ways in which the traditional jurisdiction of Australian local government can be transformed through municipal broadband may help sidestep questions of competition and municipal entrepreneurship, and bring community services into the twenty-first century. Councils could further extend standard municipal fields of community recreation, culture and informal learning into digital domains. In line with shared infrastructure policies, public libraries, local schools and other community facilities could be linked in a learning network. There could be much stronger links between local governments and the community wireless movement. Simple moves such as facilitating local networks in unregulated spectrum and fostering experimentation are well within local powers. Most urgently in some inner-city areas, incorporating digital access into the suite of community services provided for newly arrived communities could play a substantial role in their social, educational and economic participation.

The barriers are not so much due to a lack of political imagination, community, or even corporate buy-in: local digital inclusion, community networking and broadband initiatives are regularly invented, and a few flourish. The real barrier is how Australian local government thinks about its roles and responsibilities in a political environment dominated by an emphasis on the benefits of competition and consumer choice. 


\section{References}

Adelaide City Council 2013, Digital Strategy 2012-16: Connect Adelaide. Adelaide: Adelaide City Council.

Aijaz, A., Aghvami, H. and Amani, M. 2013, ‘A Survey on Mobile Data Offloading Technical and Business Perspectives', Wireless Communications, vol. 20, no. 2, pp. 104-112.

Australian Library and Information Association 2011, ALIA Internet Access in Public Libraries Survey 2011, www.alia.org.au/advocacy/internet.access/Internet.Access.Survey.2011.pdf

Australian Local Government Association 2012, Information Technology - The Role of Government, http://alga.asn.au/?ID=134.

Braue, D. 2008, 'Shocking times for Aussie broadband over powerlines', ZD Net, 8 March, www.zdnet.com/shocking-times-for-aussie-broadband-overpowerline-1339285857/.

Community Broadband Networks 2012, Wireless, http://muninetworks.org/content/wireless.

Conroy, Senator the Hon Stephen, Minister for Broadband, Communications and the Digital Economy 2009, New National Broadband Network - Media Release, 7 April 2009, available from http://www.minister.dbcde.gov.au/media/media_releases/2009/022

Crawford, S. 2013, Captive Audience - The Telecom Industry and Monopoly Power in the New Gilded Age, Yale University Press, New Haven \& London. 
Department of Communications Information Technology and the Arts 2006, Networking the Nation, www.archive.dcita.gov.au/2006/06/networking_the_nation.

Department of Communications, Information Technology and the Arts 2004, Australia's National Broadband Strategy, National Office for the Information Economy, Canberra.

Dow, A. 2013. 'City set for free Wi-Fi trial, but lagging behind other capitals', The Age, Online Edition, 18 October, www.theage.com.au/victoria/city-set-for-free-wifi-trial-butlagging-behind-other-capitals-20131017-2vpsj.html.

Eynon, R. and Geniets, A. 2012, On the Periphery? Understanding Low and Discontinuing Internet Use Amongst Young People in Britain, Oxford Internet Institute, Oxford.

Ewing, S. and Thomas, J. 2012, CCi Digital Futures - The Internet in Australia, ARC Centre of Excellence for Creative Industries and Innovation, Hawthorn.

Federal Communications Commission. 2010. Connecting America - National Broadband Plan, www.broadband.gov/plan/.

Ford, G. and Koutsky, T. 2005, "Broadband and Economic Development - A Municipal Case Study from Florida”, Applied Economic Studies, April 2005, pp. 1-17.

Fuentes-Bautista, M. and Inagaki, N. 2006, 'Reconfiguring Public Internet Access in Austin, TX - Wi-Fi's Promise and Broadband Divides', Government Information Quarterly, vol. 23, no. 2, pp. 404-434.

Gans, J. 2007, 'Looking Local on Broadband', Public Policy, vol. 2, no. 1, pp. 10-24. 
Gillett, S., Lehr, W. and Osorio, C. 2004, 'Local Government Broadband Initiatives,” Telecommunications Policy, vol. 28, no. 7-8, pp. 537-558.

Goggin, G. 2007, ‘An Australian Wireless Commons?’ Media International Australia, No. 125, pp. 118-130.

Greco, G. 2010, Municipal Networks - McArthur Fellowship Award Report, Municipal Association of Victoria, Melbourne

Hartmann, M. 2009, 'The Changing Urban Landscapes of Media Consumption and Production', European Journal of Communication, vol. 24, no. 4, pp. 421-436.

Hauge, J., Jamison, M. and Gentry, R. 2008, 'Bureaucrats as Entrepreneurs: Do Municipal Telecommunications Providers Hinder Private Entrepreneurs?', Information Economics and Policy, vol. 20, no. 1, pp. 89-102.

Higgins, A. 2012, 'High-speed Wi-Fi internet plans for Adelaide's public areas', The Advertiser, 27 November 2012, http://www.news.com.au/technology/high-speed-internetplans-for-public-areas/story-e6frfro0-1226525253897.

Jassem, H. 2010, 'Municipal Wi-Fi: The Coda', Journal of Urban Technology, vol. 17, no. 2, pp. 3-20.

Lambert, A., McQuire, S., Papastergiadis, N. 2013, Free Wi-Fi and Public Space - the State of Australian Public Initiatives, http://broadband.unimelb.edu.au/resources/whitepaper/2013/Free-Wi-Fi-and-Public-Space.pdf. 
Matson, M. and Mitchell, R. 2006, Study On Local Open Access Networks For Communities and Municipalities, World Bank, Washington DC.

McShane, I. 2010, 'Trojan Horse or Adaptive Institutions? Some Reflections on Urban Commons in Australia', Urban Policy and Research, vol. 20, no. 1, pp. 101-116.

Meredyth, D., Thomas, J., Ewing, S., and Hopkins, L. 2006, Wired High Rise - A Community-based Computer Network, Swinburne Institute for Social Research, Hawthorn.

Middleton, C. 2007, 'A Framework for Investigating the Value of Public Wireless Networks', Paper presented to the 35th Conference on Communication, Information and Internet Policy, September 2007, http://papers.ssrn.com/sol3/papers.cfm?abstract_id=2118153.

Middleton, C. 2008, ICT Infrastructure as Public Infrastructure - Connecting Communities to the Knowledge-based Economy and Society: Final Report of the Community Wireless Infrastructure Research Project, www.cwirp.ca/files/CWIRP_Final_report.pdf.

Middleton, C. \& Byrne, A. 2011. 'An Exploration of User-Generated Wireless Broadband Infrastructures in Digital Cities', Telematics and Informatics, vol. 28, no. 3, pp. 163-175.

Minister for Communications, Information Technology and the Arts 2004, Australian Government Response to the Report on Libraries in the Online Environment, http://arts.gov.au/sites/default/files/pdfs/Australian_Government_response_to_the_Senate_C ommittee_Inquiry_into_Libraries_in_the_Online_Environment.pdf. 
Molony, R. 2006, Innovative Uses of Broadband by Local Government in AustraliaDiscussion Draft, Australian Local Government Association, Canberra, www.lgconnect.gov.au/index.php?noed=844_843_206.

Morsillo, R. 2012, 'Broadband Affordability in Australia: Looking Beyond Availability', Telecommunications Journal of Australia, vol. 62, no. 5, pp. 80.1-80.16.

Newman, L., Biedzrycki, K. and Baum, F. 2010, 'Digital Technology Access and Use among Socially and Economically Disadvantaged Groups in South Australia', Journal of Community Informatics, vol. 6, no. 2, http://ci-journal.net/index.php/ciej/article/view/639.

OECD 2011, OECD Communications Outlook 2011, OECD Publications, Paris, http://dx.doi.org/10.1787/Comms_Outlook-2011-en.

Parramatta City Council 2010, Parraconnect to Explore Digital Opportunities, www.parracity.nsw.gov.au/your_council/news/parraconnect_to_explore_digitalopportunities.

Potts, J. 2014, 'Economics of public WiFi', Australian Journal of Telecommunications and the Digital Economy, vol. 2, pp. 20.1-20.9.

Powell, A. 2009, 'Wi-Fi as Public Utility or Public Park? Metaphors for Planning Local Communication Infrastructure', SSRN Electronic Journal, www.ssrn.com/abstract=1330913.

Powell, A. and Shade, L. 2006, 'Going Wi-Fi in Canada: Municipal and Community Initiatives,' Government Information Quarterly, vol. 23, no. 3-4, pp. 381-403. 
PricewaterhouseCoopers 2006, National Financial Sustainability Study of Local Government, PricewaterhouseCoopers, Sydney.

Purser, K. 2011, Using Social Media in Local Government-2011 Survey Report, Australian Centre of Excellence in Local Government, Sydney.

Rennie, E., Crouch, A., Thomas, J. and Taylor, P. 2010, 'Beyond Public Access?

Reconsidering Broadband for Indigenous Communities', Communications Policy and Culture, vol. 43, no. 1, pp. 48-69.

Ruckus Wireless. 2013, Media Release: Local Councils take the lead in public Wi-Fi offering, http://prwire.com.au/print/local-councils-take-the-lead-in-public-wi-fi-offering.

Sandvig, C. 2004, 'An Initial Assessment of Cooperative action in Wi-Fi Networking', Telecommunications Policy, vol. 28, no. 7-8, pp. 579-602.

Santorelli, M. 2007, 'Rationalizing the Municipal Broadband Debate', I/S: A Journal of Law and Policy for the Information Society, vol. 3, no. 1, pp. 43-82.

Strategic Economic Solutions 2007, The Economic Impact of a Metropolitan Broadband Network for the City of Cape Town, www.itu.int/wsis/stocktaking/docs/activities/1287143468/capetown_broadband_report.pdf.

Sylvain, O., 2012, 'Broadband Localism', Ohio State Law Journal, vol. 73, no. 4, pp. 795838. 
Talbott, E. M. 1993, Compressed Air Systems - A Guidebook on Energy and Cost Savings, Fairmont Press, Lilburn GA.

Tapia, A., Kvasny, L. and Ortiz, J. 2011, ‘A Critical Discourse Analysis of Three US Municipal Wireless Network Initiatives for Enhancing Social Inclusion', Telematics and Informatics, vol. 28, no 3, pp. 215-226.

The Goulburn Group, 2013, Goulburn Goes Wi-Fi, www.goulburngroup.com.au/.

Troulos, C. and Maglaris, V. 2011, 'Factors Determining Municipal Broadband Strategies across Europe', Telecommunications Policy, vol. 35, no. 9-10, pp. 842-856.

Van Oost, E., Verhaegh, S. and Outshoorn, N. 2011, 'Wi-Fi as Community-based Innovation', in W. Lemstra, W. Hayes and J. Groenewegen (eds.) The Innovation Journey of Wi-Fi - The Road to Global Success, Cambridge University Press, Cambridge, pp. 263-287.

Victorian Grants Commission 2013, Annual Report 2012-13, www.dpcd.vic.gov.au/_data/assets/pdf_file/0011/207776/2012-13-VGC-Annual-ReportPart-1.pdf.

Visiongain 2006. Municipal Broadband Networks - Market Impact and Implications 20062011, www.marketresearch.com/Visiongain-v1531/Municipal-Broadband-Networks-ImpactImplications-1219075/.

Willingham, R. 2014. 'Free Wi-Fi for V/Line passengers under \$40m plan'. The Age, Online Edition, 8 April, www.theage.com.au/victoria/free-wifi-for-vline-passengers-under-40mplan-20140408-36a61.html. 
Page 23 